\title{
A COVID-19 (koronavírus okozta megbetegedés) kezelési lehetőségei a fizioterápia eszközeivel, kiemelt figyelemmel a fototerápia eddigi eredményeire
}

\section{Treatment options for COVID-19 (disease caused by coronavirus) by means of physiotherapy, under special consideration of the results gained in phototherapy}

\begin{abstract}
Absztrakt
A koronavírus az egész emberiséget érinti, és a járvány az életünk minden pontját befolyásolja. Egyelöre a jelenlegi kezelési lehetőségek igen szerények. A kórházakban és a különböző szociális intézetekben a COVID-19 kockázata lényegesebben fokozott. A hon- és rendvédelmi, valamint az egészségügyi dolgozóknak a magasabb víruskoncentrációval való kitettsége különösen súlyos betegek kezelése esetén jelentős. Jelenleg minden egészségügyi dolgozó a frontvonalban tevékenykedik. Mindenki sokat dolgozik, kimerült és állandó stresszhatás alatt van. Az utóbbi néhány hónapban a nemzetközi szakirodalomban több cikk jelent meg, hogy a kezelésében, valamint profilaktikusan a lágylézer-terápia lehetőségét célszerü igénybe venni. A betegség és a járvány terjedését a korai felismerés, az izoláció, a vakcina és a betegek gyors terápiás ellátása akadályozhatja meg.
\end{abstract}

Kulcsszavak: COVID-19, ARDS, citokinvihar, lágylézer-terápia, gyulladáscsökkentés, lélegeztetőgép, biostimuláció

\begin{abstract}
The coronavirus affects the whole humanity and the epidemic influences all aspects of our lives. So far, the current treatment options are very modest. The risk of COVID-19 is significantly increased in hospitals and various social institutions. The exposure of law enforcement and health care workers to higher
\end{abstract}


viral concentrations is significant in the treatment of particularly severe patients. Currently, all healthcare workers are on the front lines. Everyone works a lot, is exhausted and is under constant stress. In the last few months, several articles have appeared in the international literature that the possibility of soft laser therapy should be used in treatment as well as prophylactically. The spread of the disease and the epidemic can be prevented by early detection, isolation, vaccine, and rapid therapeutic care of patients.

Keywords: COVID-19, ARDS, cytokine storm, soft laser therapy, reducing inflammation, ventilator, biostimulation

\section{Bevezetés}

E tanulmány írásakor Magyarország a COVID-19 járvány platófázisában, a második hullám közepén, talán a harmadik hullám küszöbén áll. Egy olyan pandémia érintettjeivé váltunk, a világ csaknem minden országához hasonlóan, amelyet eddig többnyire - a jelenlegi helyzethez kísértetiesen hasonló történeteket megelevenítö - filmekből, illetve epidemiológus szakemberek elöjelzéseiből ismerhetünk (Woodruff et al., 2004). A modern kor embere, az átlag szemlélő, aki eddig a világ veszélyeitől távollévőnek és a minden bajtól védettnek, oltottnak érezte magát, most érthetetlenül áll az események sodrában. A 2020-as év számunkra is nem várt tapasztalatokkal szolgált. Míg a pandémia első hulláma a gyorsan bevezetett szigorú és hatékony intézkedések révén csak súrolt minket, utólag visszatekintve aránylag kedvezően és nagyobb tragédiák nélkül hamis biztonságképet alakított ki bennünk. Mára a napi fertőzöttségi és mortalitási adatok nem hasonlíthatók a tavaszi értékekhez, egyre közelebbről érintenek bennünket, és most már ismerünk számos olyan közeli ismerőst, barátot, esetleg közvetlen családtagot, akik megfertőződtek vagy sajnálatos módon elhunytak.

\section{Pandémia}

A közösségben élőket - embereket, állatokat - egyaránt sújtották fertőző betegségek. Az ismereteink, valamint az orvostudomány fejlődésének köszönhetően egyre kevesebb, illetve egyre enyhébb lefolyású megbetegedésekkel találkozott a nyugati civilizáció az elmúlt években. De nemcsak az emberek immunrendszere változott meg, hanem a kórokozók jellege, múködése is (Derbenev et al., 2000). Míg némely mikroorganizmus csak az állatokat fenyegeti, mások 
átterjedhetnek az emberekre is, megfertőzve azokat. Ilyen például az influenza vagy a HIV vírus. Ha immunrendszerünk nem tud védekezni a szervezetbe került kórokozóval szemben, megbetegszik, ha sokan megbetegednek és világméretűvé - több kontinensre kiterjedővé - válik a járvány, akkor pandémiáról beszélünk. A nagyobb területet, akár egy vagy több kontinens populációját érintő fertőző betegséget az egészségügyi világszervezet hivatott kihirdetni.

Ahhoz, hogy járványról beszélhessünk, három feltételnek kell teljesülnie:

- a kórokozó anyag,

- a fertőzés terjedését lehetővé tevő körülmények,

- és a fertőzésre fogékony szervezet.

Az emberiség történelme során gyakran bukkantak fel fertőző anyagok, kórokozók (Liang, 2020). A fertőzésre fogékony szervezet is rendszeresen rendelkezésre állt - az évszázados regionális vagy globális háborúk vagy a zsúfolt és egészségtelen városok -, de a fertőzések terjedéséhez már szükség volt a technikai fejlődésre is: a megélénkült kereskedelem, a mind nagyobb tömegek egyre távolabb kerülése a lakóhelyétől, azaz a kórokozó anyag eljuttatása csak ekkor lendült fel igazán. A megfertőződéstől való félelem kiváltotta menekülés csak tovább rontotta a helyzetet. És az emberi magatartás, mint legjellemzőbb tényező sem hagyható ki a pandémia egyenletéből. Gondoljunk csak a COVID-19 tavaszi, első hullámára, amikor a nagyobb városokat elhagyó, vidéki nyaralóikba menekülö norvég vagy skót emberek, akik eljuttatták a korábban vírusmentes területekre a fertőzést, ezáltal elképzelhetetlen terhet róva az egészségügyi ellátórendszerre (Teijaro, 2011).

\section{Világjárványok}

Az emberiséggel egyidős járványok időről időre felbukkannak, majd eltünnek. A történelem során több világméretű járvány tört ki, mely emberek millióit pusztította el. Nagyrészüket szerencsére csak történelemkönyvekből ismerjük, például a fekete halál, azaz a pestis vagy a kolera, a kiütéses tífusz, amely a krími háborúban szedte áldozatait, a vérhas, mely szintén a háborúk velejárója volt. Ezek jelentőségét növeli az a tény, hogy ezen korok háborúiban többen haltak meg fertőző betegségekben, mint a háború során elszenvedett, fegyverek által okozott sérülésekbe (Bjordal et al., 2010).

Új dimenziót jelentett a 20. század elején megjelent, H1N1 antigénstruktúrájú influenza vírus által okozott spanyolnátha, a 20. század leggyilkosabb 
járványa, mintegy elővetítve napjaink legégetőbb problémáját, a koronavírus okozta pandémiát. A trópusi égövi területeken dúló háborúk rendszeres velejárója volt a sárgaláz és a váltólázként is ismert malária, mely napjainkban is népbetegségnek tekinthető, áldozatainak száma éves szinten meghaladja az egymillió főt. Az elsősorban Afrikába jelentős járványokat okozó ebola virulens volta és magas halálozási aránya (90\%) biológiai fegyverek alapanyagául szolgálhat. A spanyolnátha a Föld lakosságának mintegy 20-40\%-át betegítette meg, több halálos áldozatot követelt, mint az I. világháború. A vírus a 20-40 éves korosztályt támadta meg. Ennek egyik oka lehetett a frontszolgálatos életkor - az ottani nem megfelelő higiéniás körülmények, zsúfoltság, alultápláltság, mindezek következményeképpen kialakult legyengült immunrendszer -, a másik lehetséges ok pedig, hogy ez a korosztály nem találkozott korábban a vírussal, így nem alakulhatott ki immunitás a szervezetben egy korábban átvészelt influenzás megbetegedés eredményeképpen. A betegség lefutása rendkívül gyors volt, hirtelen felszökő láz, hidegrázás, fejfájás, végtagfájdalom, köhögés jellemezte. Míg egyesek enyhe tünetekkel, szövődmények nélkül átvészelték, addig a többség 24 órán belül, vérzéses tüdőgyulladásban életét vesztette. Ilyen veszélyes vírussal azóta sem találkoztak a szakemberek.

A legutóbbi világjárványok:

- 1889 - orosznátha (H2N2).

- 1918 - spanyolnátha (H1N1).

- 1957 - ázsiai influenza (H2-N2).

- 1968 - hong-kongi influenza (H3N2).

- 2009 - influenza (H1N1).

\section{A 21. század járványügyi kihívója, a SARS (Súlyos Akut Légzőszervi Szindróma - Severe Acute Respiratory Syndrome)}

A21. század első és egyben leggyorsabban terjedő járványa a 2002 novemberében Kínában kitört Súlyos Akut Légzőszervi Szindróma volt. Annak ellenére, hogy nem érintett nagy tömegeket, így nem vált világjárvánnyá, mégis régóta nem tapasztalt pánikot okozott. Befolyással bírt a nemzetközi kereskedelemre, a turizmusra, a tőzsdékre. A sok évtizedes nyugalmi állapot után először kezdett félni a civilizált ember egy fertőzéstől, amelyben akár meg is halhat. A vírus terjedéséért a denevéreket és a cibetmacskát teszik felelőssé (Ostronosova, 2006). A vírus a jelenlegi pandémiát okozó koronavírus családjába tartozik. A koronavírusok 
egy nagy víruscsalád, amely megbetegítheti az embereket és az állatokat, de bizonyítottan emberről emberre is terjed. Olyan betegségeket okoznak, amelyek a náthától a súlyosabb betegségekig, akár halálig terjedhetnek. Terjedése testi érintkezés, tüsszentés, köhögés, beszéd útján cseppfertőzéssel valósul meg. Lappangási ideje: 2-14 nap. A koronavírus az angiotenzin-konvertáló enzim receptoron keresztül kötődik a sejtekhez, amely a tüdö- és szívsejtekben, az emberi légzőszervi és szaglóhámban nagymértékben expresszálódik, és emiatt a vírus fő támadási területe a gyomor-bélcsatorna nyálkahártya, tüdő- és szívszövet.

\section{Világjárvány, ami megváltoztatta az életünket}

Három hónap alatt (2019. december - 2020. március) a 2019-es koronavírus betegség (COVID-19) világjárvánnyá vált, amelyet egy - az előzőekben már említett - zoonotikus vírus okozott. A súlyos akut légzőszervi szindróma, a koronavírus 2 (SARS-CoV-2), soha nem látott és mély hatást, valamint aktivitást váltott ki az orvosbiológiai kutatások több területén. 2020. január 30-án a WHO a H1N1 (2009), a gyermekbénulás (2014), a nyugat-afrikai Ebola (2014) és a Zika (2016) után a nemzetközi aggodalomra okot adó hatodik közegészségügyi vészhelyzetnek nyilvánította a COVID-19 járványt.

\section{1. számú ábra: Sars-CoV-2 vírusfertőzés, citokinvihar}

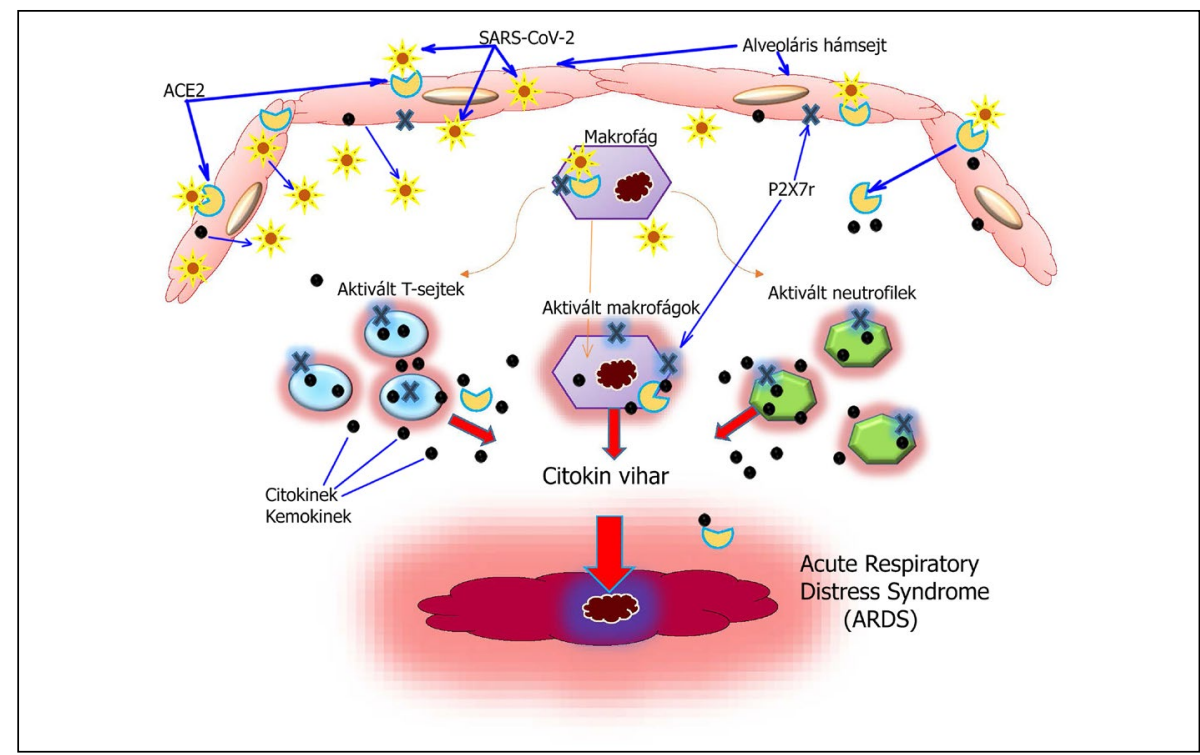

Forrás: Mokmeli, 2020. 
A megbetegedés patomehanizmusát röviden áttekintve, jelenlegi ismereteink szerint, a megtámadott sejtek apoptózisa után azok lefele áramlanak és ez a törmelék elzárja a légutakat és a vírus így egyre mélyebbre kerül a tüdőbe. Mivel a légutak eltömődnek az elhalt sejtektől és a folyadéktól a légzés egyre nehezebbé válik. Az immunrendszer aktiválódik és megtámadja a vírust, gyulladást és lázat kiváltva ezzel. Az immunrendszer úgymond megvadul és egyre több kárt okoz, mint maga a vírus. Az erek dilatációja megy végbe, áteresztőképességük és a microcirkuláció fokozódik, a tüdő elkerülhetetlenül egyre több folyadékkal telítódik. Ezt a túlzott immunválaszt nevezik citokinviharnak, ami ARDS-hez (acute respiratory distress syndrome - akut légúti distressz szindróma) hasonló kórképhez, lázhoz, multiorganikus elégtelenséghez és halálhoz vezet. A citokinvihar egyéb szerveket is érint, különösen abban az esetben, ha különböző egyéb krónikus betegségben is szenved a beteg (1. számú ábra).

A COVID-19 kezdetén, amikor a SARS-CoV-2 az ACE2-t használja a fertőzés belépési receptoraként (Mehta et al., 2020), indukálja az ACE2 szabályozását és leválását. Az angiotenzin-konvertáz 2 (ACE2) egy olyan enzim, amely többnyire az orrnyálkahártyában, a hörgőben, a tüdőben, a szívben, a nyelőcsőben, a vesében, a gyomorban, a hólyagbam és az ileumban expresszálódik, így ezek a szervek mind fogékonyak a SARS-CoV-2-re és fö befogadói a vírus tüskefehérjéinek (Tumilty et al., 2010). Az elsődleges vírusreplikáció a felső légutak (orrüreg és garat) nyálkahártya-epitéliumában fordul elő, az alsó légúti traktusban és a gyomor-bélrendszer nyálkahártyájában további szaporodás várható. Az ACE2 elvesztése az endothelből a renin-angiotenzin rendszer diszfunkcióját okozza, és fokozza a gyulladást és az érpermeabilitást (Hamblin, 2017). Az ACE2 endotheliumból történő leválasztása enzimatikusan aktív oldható ACE2-t (sACE2) szabadít fel, amely szorosan kapcsolódik a tumor nekrózis faktor alfa (TNF-a) termeléséhez a sejttenyészetben (Damjanovic et al., 2012). A vírusok megfertőzhetik a felső vagy alsó légutakat. A felső légúti fertőzések enyhébbek, fertőzőbbek és könnyebben ráterjednek az alsó légutakra, így veszélyessé válhatnak. A felső légutak (az orr, a garat, a gége és a nagy légutak). Az alsó légúti fertőzések ritkábban alakulnak ki, viszont igen súlyosak és rendkívül veszélyesek. A tünetek az enyhe köhögéstől a tüdőgyulladásig terjednek. A globális járványos COVID-19 fertőző betegség, halálozási aránya 1-5\% között valószínűsíthetően akut légzési distressz szindróma (ARDS) és a citokinvihar miatt következik be. Az intubatiot igénylő betegek jelentős része lélegeztető gépre szorul, de sajnos a lelkiismeretes kezelések ellenére is magas a halálozások (50\% körüli) aránya. Vannak, akik könnyen felépülnek, mások nagyon gyorsan megbetegedhetnek. 


\section{A súlyos betegség kockázati tényezői}

A járvány tavaszi hulláma megmutatta, hogy a több rizikófaktorral rendelkező betegekre mennyire veszélyes (Smoot et al., 2014), hiszen különböző légúti szövődmények léphetnek fel. A rendkívül nagytömegü lélegeztetőgépes betegellátásra egyetlen kórház sincs felkészülve. Nincs elegendő kiképzett személyzete (3-4 év egy megfelelő képzés és rengeteg gyakorlati eset), futószalagon nem lehet pótolni ezeket az embereket. A lélegeztetőgép nem megfelelö beállítása esetén barotrauma léphet fel a nagy nyomás miatt, illetve volutrauma a túlfújás esetén, ami tovább rontja az ARDS-t és ugyanakkor bevérzések is kialakulhatnak (2. számú ábra).

2. számú ábra: A lágylézer-terápia besugárzás hatásai COVID fertőzés esetén

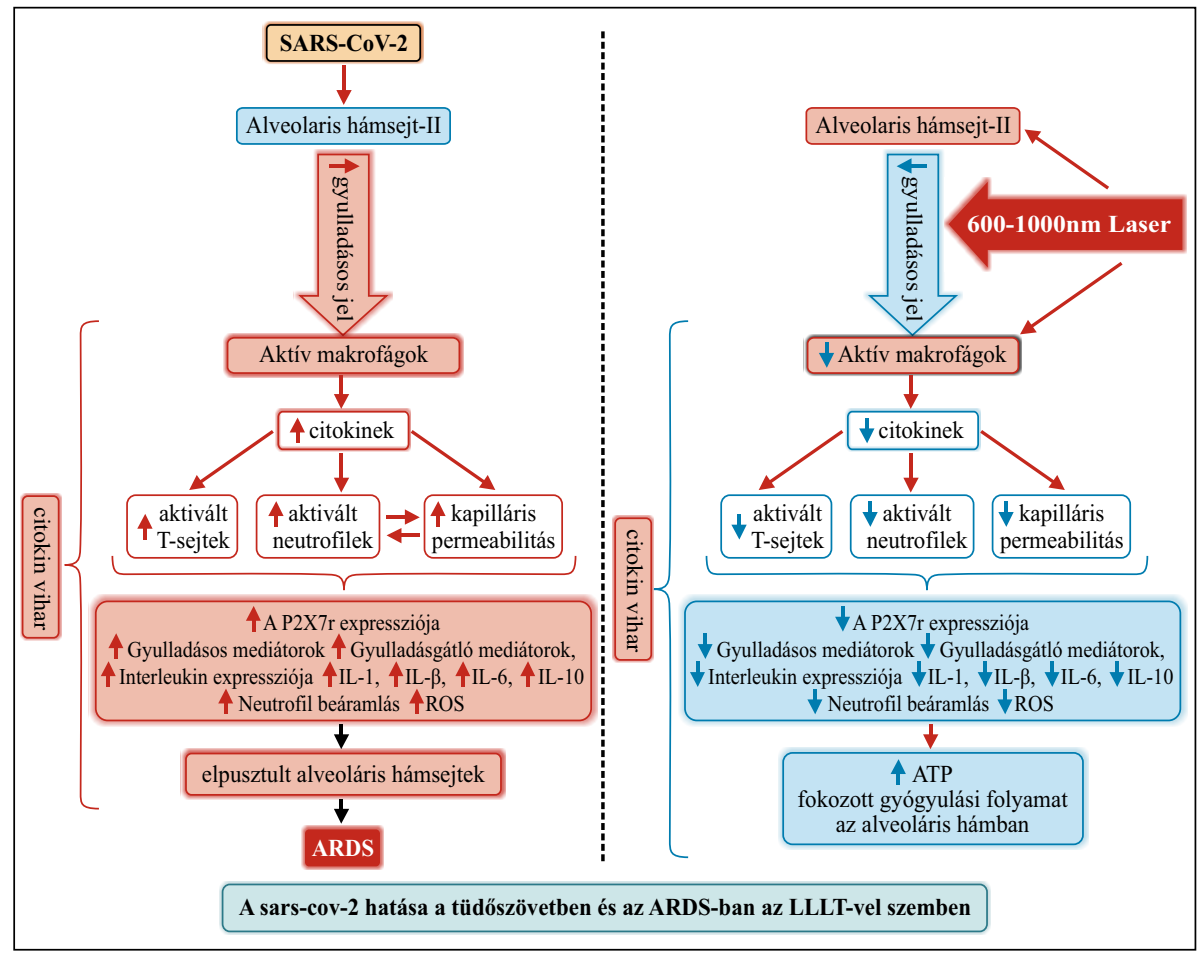

Forrás: Mokmeli, 2020.

Az eddigi tapasztalatok alapján a lágylézer-terápiával elő lehetett segíteni, hogy a betegek hamarabb lekerüljenek a lélegeztetőgépröl, illetve rövidebb ideig tartott az oxigén terápiájuk (Cotler et al., 2015). Megjelentek már olyan cikkek is, hogy amikor a betegség legelső tünetei megjelentek és azonnal elkezdték alkalmazni a lágylézer-terápiát, a betegség gyorsabban szanálódott (Jang \& Lee, 2012). 
1. számú táblázat: A COVID-19 fokozatai és klasszifikációi

\begin{tabular}{|c|c|c|c|}
\hline Klasszifikáció & Tünetek & Képalkotás & $\begin{array}{c}\text { Légzési } \\
\text { kritériumok }\end{array}$ \\
\hline $\begin{array}{l}\text { Aszimpto- } \\
\text { matikus/ } \\
\text { Preszimpto- } \\
\text { matikus }\end{array}$ & Negatív & Negatív & Normál \\
\hline \multirow{9}{*}{ Enyhe } & láz, hőemelkedés & \multirow{9}{*}{$\begin{array}{l}\text { Nincs tüdőgyulladásra } \\
\text { utaló jel }\end{array}$} & \multirow{9}{*}{ Normál } \\
\hline & $\begin{array}{l}\text { fáradtság, rossz } \\
\text { közérzet, }\end{array}$ & & \\
\hline & $\begin{array}{l}\text { fejfájás, fülzúgás, } \\
\text { herpesz, ájulás, } \\
\text { syncope, repedezett } \\
\text { száraz ajkak, üvegtesti } \\
\text { homály }\end{array}$ & & \\
\hline & $\begin{array}{l}\text { orrdugulás, torokfájás, } \\
\text { száraz köhögés } \\
\text { (köpetképződéssel } \\
\text { vagy anélkül) }\end{array}$ & & \\
\hline & étvágytalanság & & \\
\hline & izomfájdalom & & \\
\hline & kötőhártya-gyulladás & & \\
\hline & szag- és ízvesztés & & \\
\hline & $\begin{array}{l}\text { hányinger, hányás, } \\
\text { hasmenés, hasi } \\
\text { fájdalom }\end{array}$ & & \\
\hline \multirow{8}{*}{ Közepes } & 38 fok feletti láz & \multirow{8}{*}{$\begin{array}{l}\text { Tüdőgyulladás pozitív } \\
\text { jelei }\end{array}$} & \multirow{8}{*}{ Normál } \\
\hline & súlyosbodó köhögés & & \\
\hline & $\begin{array}{l}\text { légszomj vagy légzési } \\
\text { nehézség, de oxigénre } \\
\text { nem szorul }\end{array}$ & & \\
\hline & $\begin{array}{l}\text { izom- illetve test- } \\
\text { bőrfájdalmak }\end{array}$ & & \\
\hline & szag- vagy ízvesztés & & \\
\hline & $\begin{array}{l}\text { bőrkiütés vagy } \\
\text { elszíneződés az } \\
\text { ujjakon/lábujjakon }\end{array}$ & & \\
\hline & fejfájás & & \\
\hline & $\begin{array}{l}\text { gyomor-bélrendszeri } \\
\text { tünetek (hasi fájdalom, } \\
\text { hasmenés, hányás) }\end{array}$ & & \\
\hline
\end{tabular}




\begin{tabular}{|c|c|c|c|}
\hline Klasszifikáció & Tünetek & Képalkotás & $\begin{array}{c}\text { Légzési } \\
\text { kritériumok }\end{array}$ \\
\hline \multirow[b]{2}{*}{ Súlyos } & $\begin{array}{l}\text { nyomás vagy fájdalom } \\
\text { a mellkasi régióban }\end{array}$ & \multirow{2}{*}{$\begin{array}{l}\text { Kétoldalú } \\
\text { homályosságok, } \\
\text { amelyeket nem } \\
\text { magyaráz teljes } \\
\text { mértékben a térfogat } \\
\text { túlterhelése }\end{array}$} & \multirow{2}{*}{$\begin{array}{l}\geq 30 / \text { min légzési ráta } \\
\mathrm{O}_{2} \text { szaturáció } \leq 93 \% \\
\left(\mathrm{PaO}_{2}\right) /\left(\mathrm{FiO}_{2}\right) \leq 300 \\
\mathrm{~mm} \mathrm{Hg}\end{array}$} \\
\hline & $\begin{array}{l}\text { légzési nehézség, } \\
\text { illetve légszomj }\end{array}$ & & \\
\hline \multirow{6}{*}{ Kritikus } & $\begin{array}{l}\text { beszédképesség } \\
\text { elvesztése }\end{array}$ & \multirow{6}{*}{$\begin{array}{l}24-48 \text { órán belül } \\
\text { laesiok mutatkoznak } \\
\text { a tüdő felvételen } \\
\text { kétoldalú } \\
\text { homályosságok, } \\
\text { amelyeket nem } \\
\text { magyaráznak } \\
\text { teljes mértékben } \\
\text { a térfogat túlterhelése, } \\
\text { a lebeny vagy a tüdő } \\
\text { összeomlása vagy } \\
\text { a csomók. }\end{array}$} & $\begin{array}{l}\text { korai: } \\
\text { Oxigenációs index: } \\
100.1-149.9 \mathrm{mmHg} \\
\mathrm{RSC} \geq 30 \mathrm{ml} / \mathrm{cmH}_{2} \mathrm{O} \\
\text { a tüdőn kívül más } \\
\text { szerv nem érintett }\end{array}$ \\
\hline & mozgásképtelenség & & \multirow{4}{*}{$\begin{array}{l}\text { középsö: } \\
60 \mathrm{mmHg}<\mathrm{O}_{2} \text { index } \\
\leq 100 \mathrm{mmHg} \text {. } \\
30 \mathrm{~mL} / \mathrm{cmH}_{2} \mathrm{O}>\text { RSC } \\
\geq 15 \mathrm{~mL} / \mathrm{cmH}_{2} \mathrm{O} . \\
\text { egyéb szervek is } \\
\text { érintettek enyhe vagy } \\
\text { közepes mértékben }\end{array}$} \\
\hline & légzési elégtelenség & & \\
\hline & sokk & & \\
\hline & $\begin{array}{l}\text { egyéb szervi } \\
\text { elégtelenség }\end{array}$ & & \\
\hline & $\begin{array}{l}\text { monitorozás, intenzív } \\
\text { ellátás }\end{array}$ & & $\begin{array}{l}\text { késői: } \\
\mathrm{O}_{2} \text { index } \leq 60 \mathrm{mmHg} \text {. } \\
\mathrm{RSC}<15 \mathrm{~mL} / \mathrm{cmH}_{2} \mathrm{O} \text {. } \\
\text { mko tüdőfél diffúze } \\
\text { gyengülése, mely } \\
\text { lélegeztetést igényel. }\end{array}$ \\
\hline
\end{tabular}

Forrás: A 2020. évben azonosított új koronavírus (SARS-CoV-2)

okozta fertőzések (COVID-19) megelőzésének és terápiájának kézikönyve.

Emberi Erőforrások Minisztériuma 2020. 06. 25.

A koronavírusok súlyos betegségeket okozhatnak egyes közösségekben élö emberek számára (1. számú táblázat). Akik veszélyeztetettek a súlyosabb betegség vagy a COVID-19 kimenetelének kialakulásában, azok az emberek:

- akik idősebb felnőttek (minden évtizedben növekszik a kockázat, különösen 60 év felett);

- akik dohányoznak;

- akik várandósok.

Ezen kívül bármilyen korú, krónikus betegségben szenvedők, beleértve:

- krónikus obstruktív tüdőbetegség (COPD),

- asztma, 
- szívbetegség,

- magas vérnyomás,

- 1-es és 2-es típusú diabétesz,

- vesebetegség,

- májbetegség,

- sarlósejtes anaemia,

- elmebaj,

- stroke.

Ide kell még sorolnunk a bármely korú, immunhiányos személyeket is:

- alapbetegséggel élők, például carcinoma,

- olyan gyógyszereket szedők, amelyek csökkentik az immunrendszert (kemoterápia),

- szervátültetéstől gyengült immunrendszerüek,

- elhízással élők (40 vagy magasabb BMI).

\section{COVID-19 lehetséges kezelése}

A COVID-19 pandémia kapcsán a legnagyobb probléma az akut respiratorikus kórállapot (ARDS), a tartós légzésfunkciós károsodás megakadályozása és a szövődmények elhárítása. ARDS esetében gyakran elengedhetetlen az invazív mechanikai légzéstámogatás. A COVID-19 betegség nagy mortalitásának oka többnyire az alsó végtagi vénákból származó pulmonalis embolia, a kiterjedt mikrovaszkuláris pulmonalis thrombosis (a tüdő kisereinek trombózisa). A SARS-CoV-2 kezelésére jelenleg nincs megbízható kezelés, a jelenlegi kezelések az antivirális, immunreguláció, gyulladáscsökkentő, a citokinvihart elfojtó és a szövetek oxigénellátásának fokozására összpontosítanak, valamint a társult betegségek szuppozitív kezelésére.

- A kórházi betegek kiegészítő oxigént vagy mechanikus lélegeztetést igényelnek.

- Gyógyszeres kezelés.

Már az első hullám után felgyógyult betegek esetén is megállapították, hogy a betegség után visszamaradó szövődmények és állapotok további kezelésében a rehabilitációnak nagy jelentősége lehet. És itt jön el a fizioterápia szerepe és jelentősége, amelyet más országokban a COVID-19 akut eseteiben, illetve rehabilitációjában már alkalmaznak az alábbi eljárások és eszközök segítségével: 
- gyógytorna (a test pozícionálása, a légutak kitisztítási technikája, a belégző izmok edzése);

- fototerápia (lágylézer-terápia, Bioptron) $(1,2)$;

- egyéb fizikoterápia (TENS, magnevit, BEMER, mágneses erőtér terápia).

\section{Új lehetőség a lágylézer-terápia a COVID-19 kezelési (rehabilitációs) protokollban}

A lágylézer-terápia az 1960-as évek közepén indult világkörüli útjára, dr. Mester Endre sebész professzor különböző vizsgálatai, kutatási eredményei útján. Magyarországon még mindig nincs olyan elterjedtsége, mint a világ egyéb részein, ahol szinte hetente jelennek meg újabb terápiás eredmények különböző betegségekkel kapcsolatban. Amerikában, Európában is több terápiás lézer kezelést végeztek COVID-19-es betegek esetén és rendkívül biztató eredmények születtek. Egy 57 éves afroamerikai férfi kórtörténetében magas vérnyomást és asztmát írtak le. A tünetek között szerepelt a légszomj, súlyos kiszáradás, akut veseelégtelenség és difficile-pozitív hasmenés. Fizikális vizsgálat során nehézlégzést, gyengeséget, fáradékonyságot észleltek. A mellkas röntgenfelvételen a kétoldali tüdőinfiltrátum súlyossága fokozódott, a beteg oxigén igénye 2-6 liter/perc között volt. Légzési elégtelenség alakult ki, a $\mathrm{SpO}_{2} 80 \%$-ra csökkent, ezért a beteget intenzív osztályon kezelték tovább, ahol 48 órán át $61 /$ perc áramlással $\mathrm{O}_{2}$ terápiában részesült. A SARS-CoV-2 fertőzés diagnózisát nasopharyngealis tamponnal vett vizsgálati anyagon reverz transzkripció-polimeráz láncreakcióval igazolták, Abbott ID rendszeren. Ezt követően a beteg hozzájárult lézeres kezeléshez (Amirov, 2002). A lézeres kezeléstől számított öt percen belül oxigéntelítettsége 94\%-ról 100\%-ra emelkedett az első ülésen. A kezelést követően visszatért az ágyába, folytatta a félig ülö helyzetet, és az $\mathrm{SpO}_{2} 98 \%$-on maradt a nap hátralévő részében. A beteg négy napon keresztül rendszeresen lágylézer-kezelést kapott, és minden kezelés után azonnal jelentős javulást tapasztalt a légzésben (3. számú ábra). A paroximális köhögési rohamok a harmadik kezelés után megszüntek. A negyedik kezelés befejezése után a beteg fizikoterápiával tudott ambulánsan mozogni a szobában. A végső kezelést követő napon a beteget 1 1/perc oxigénnel akut rehabilitációs intézetbe engedték (Huang et al., 2020). Az akut rehabilitációs intézetbe való megérkezés utáni napon a páciens két lépcsőmászási kísérletet tudott elvégezni fizikoterápiával. Ez az esettanulmány megmutatta, hogy a kiegészítő biostimuláció négy napi kezelés hatásos volt súlyos COVID-19 tünetekkel küzdő betegeknél. A beteg kezelésre adott pozitív válaszát radiológiai eredmények, a tüdő súlyossági mutatói, az oxigénigény, a vérés gyulladásos markerek, valamint a beteg kérdőívei támasztották alá. 
3. számú ábra: Lágylézer-terápia besugárzás COVID-19 okozta tüdőgyulladás esetében
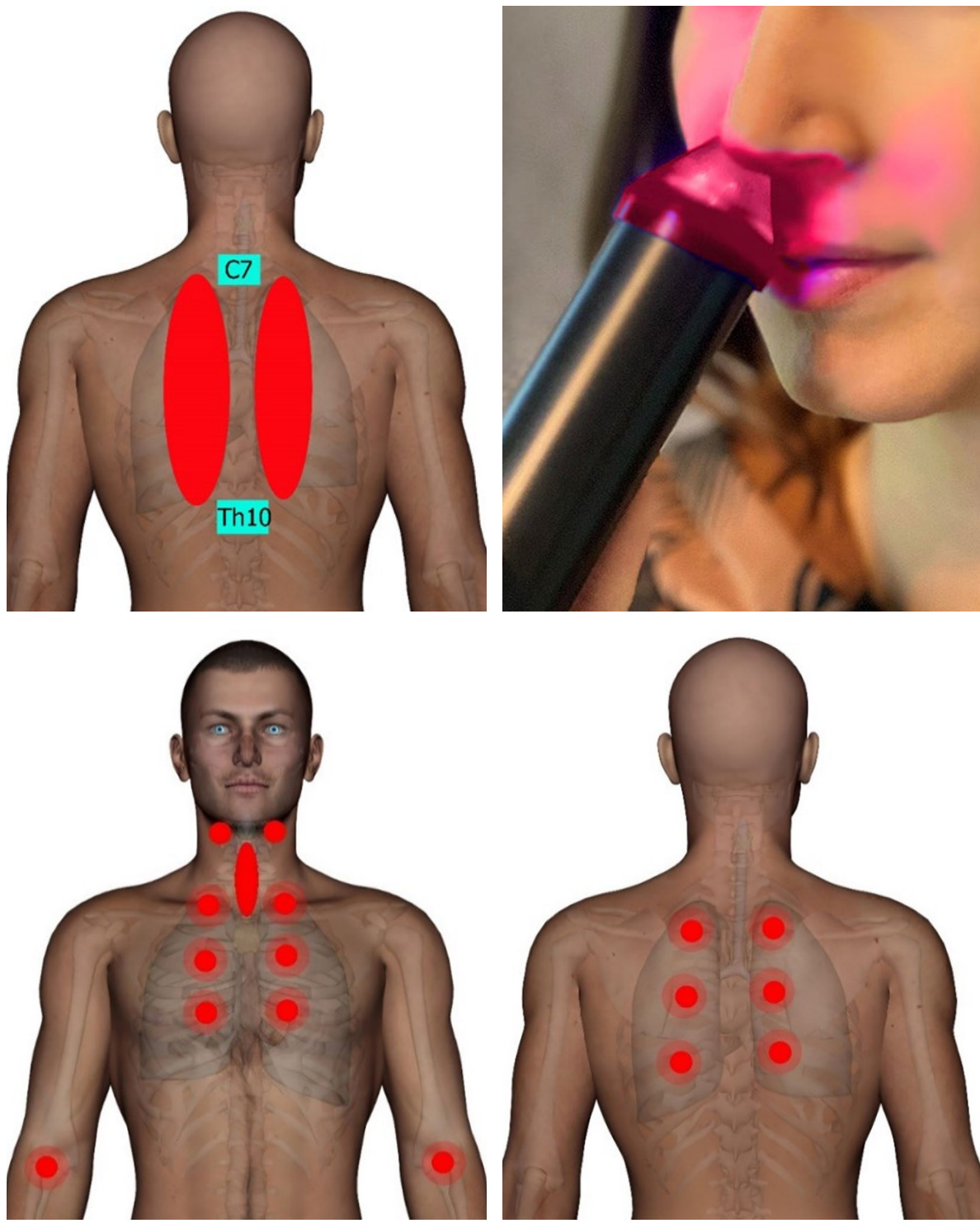

Forrás: Mokmeli, 2020.

A nyomon követés során klinikai gyógyulása összesen három hét volt, míg a COVID-19 medián ideje általában 6-8 hét. Ez a kórleírás egy súlyos COVID-19 tüdőgyulladásban szenvedő beteget mutatott be, akit fotobiomodulációs terápiában (PMBT) részesítettek. Ezen esettanulmány, valamint a PBMT klinikai 
tapasztalatai alapján a COVID-19 kezelésének megvalósítható kiegészítő módjának tekintjük a tüdőszövetre gyakorolt gyulladáscsökkentő hatása miatt. Javasoljuk, hogy a kiegészítő PBMT alkalmazása a COVID-19 betegeknél megfigyelt súlyos ARDS korai szakaszában fokozhatja a gyógyulást és csökkentheti a hosszantartó lélegeztetőgép-támogatás és az ICU-tartózkodás szükségességét (Wu, Z. \& McGoogan, 2019). A sürgős jelenlegi orvosi helyzet megköveteli a PMBT kísérleti és klinikai vizsgálatokat annak értékelésére, hogy milyen hatása van a COVID-19 tüdőgyulladásra. Ez a beteg egy folyamatban lévő, randomizált, kontrollált, kontrollos vizsgálat része (Erkinovna et al., 2006).

\section{Összegzés}

A Magyar Honvédség Egészségügyi Központban kb. 35 éve alkalmazzuk a lágylézer-terápiát különböző diagnózisokban, főleg izomfájdalmak, idegi fájdalmak és bőrgyógyászati megbetegedések esetén. Ahogy a szakrendelések elkezdték felfedezni sokoldalúságát ezen fizioterápiás kezelésnek, úgy számos allergiás betegnél is alkalmazni kezdtük kiemelkedő eredménnyel. Voltak olyan betegek, akik a tíz alkalmas kúrát ki sem használták, mert már öt alkalom után is szinte teljesen megszüntek az allergiás tüneteik, légzési problémáik. A neurológiában facial paresises betegeknél idegregenerációra alkalmazva a szelektív ingeráram mellett sokkal gyorsabban értünk el változást és teljes gyógyulást. A COVID-19 betegeknél a korai és közép szakaszban megakadályozható lenne a vírusfertőzés tovább terjedése az alsó légúti szakaszra, vagyis a tüdőgyulladás kialakulása. A COVID-19 fertőzés után szövődményként visszamaradó föképpen izom-, ízületifájdalom és fáradtság véleményünk szerint a lágylézer-terápiával nagymértékben befolyásolható és kezelhető, osztályunkon öt betegnél már sikeresen alkalmaztuk a fertőzés után visszamaradt nagyízületi fájdalmaikban.

\section{Felhasznált irodalom}

Amirov, N.B. (2002). Parameters of membrane permeability, microcirculation, external respiration, and trace element levels in the drug-laser treatment of pneumonia. Article in Russian, 74(3), 40-3.

Bjordal, J.M., Lopes-Martins, R.A.B. \& Iversen V.V. (2010). The anti-inflammatory mechanism of low level laser therapy and its relevance for clinical use in physiotherapy. Physical Therapy Reviews, 15(4), 286-293. https://doi.org/10.1179/1743288X10Y.0000000001 
Cotler, H.B., Chow, R.T., Hamblin, M.R. \& Carroll, J. (2015). The use of Low Level Laser Therapy (LLLT) for musculoskeletal pain. MOJ Orthop Rheumatol, 2(5), 00068. https://doi. org/10.15406/mojor.2015.02.00068

Damjanovic, D., Small, C.L. \& Jeyanathan, M., et al. (2012). Immunopathology in influenza virus infection: uncoupling the friend from foe. Clin Immunol, 144(1), 57-69. https://doi.org/10.1016/j.clim.2012.05.005

Derbenev, V.A., Mikhailov, V.A. \& Denisov, I.N. (2000). Use of low-level laser therapy (LLLT) in the treatment of some pulmonary diseases: ten-year experience. Proceedings of the SPIE, 4166(6), 323-325. https://doi.org/10.1117/12.389506

Erkinovna, T.B. \& Tulkunovna, M.H. (2006). Efficacy of laser therapy in infants with infectious-inflammatory respiratory diseases. АКРОНИМ: European Science Review; 4, 105-106.

Hamblin, M.R. (2017). Mechanisms and applications of the anti-inflammatory effects of photobiomodulation. AIMS Biophys, 4(3), 337-361. https://doi.org/10.3934/biophy.2017.3.337

Huang, C., Wang, Y. \& Li, X. et al. (2020). Clinical features of patients infected with 2019 novel coronavirus in Wuhan. The Lancet, 395(10223), 1-10. https://doi.org/10.1016/S01406736(20)30183-5

Jang, H. \& Lee. H. (2012). Meta-analysis of pain relief effects by laser irradiation on joint areas. Photomed Laser Surg, 30(8), 405-417. https://doi.org/10.1089/pho.2012.3240

Liang, T. (2020). According to clinical experience. Handbook of Covid19 prevention and treatment. Zhejiang University School of Medicine, Hangzhou

Mehta, P., McAuley, D.F. \& Brown, M., et al. (2020). COVID-19: consider cytokine storm syndromes and immunosuppression. The Lancet, 395(10229), 1033-1034. https://doi.org/10.1016/ S0140-6736(20)30628-0

Mokmeli, S. \& Vetrici, M. (2020). Low level laser therapy as a modality to attenuate cytokine storm at multiple levels, enhance recovery, and reduce the use of ventilators in COVID-19. Can J Respir Ther, 56, 25-31. https://doi.org/10.29390/cjrt-2020-015

Ostronosova, N.S. (2006). Outpatient use of laser therapy in bronchial asthma. TerArkh, 78(3), 414.

Smoot, B., Chiavola-Larson, L., Lee, J., Manibusan, H. \& Allen, D.D. (2014). Effect of low-level laser therapy on pain and swelling in women with breast cancer-related lymphedema: a systematic review and meta-analysis. J Cancer Survivorship, 9(2), 287-304. https://doi. org/10.1007/s11764-014-0411-1

Teijaro, J.R., Walsh, K.B. \& Cahalan, S., et al. (2011). Endothelial cells as regulators of cytokine storms during influenza infection. Cell, 146(6), 980-991. https://doi.org/10.1016/j. cell.2011.08.015

Tumilty, S., Munn, J., McDonough, S., Hurley, D.A., Basford, J.R. \& Baxter, G.D. (2010). Low level laser treatment of tendinopathy: a systematic review with meta-analysis. Photomed Laser Surg, 28(1), 3-16. https://doi.org/10.1089/pho.2008.2470

Woodruff, L.D., Bounkeo, J.M. \& Brannon, W.M., et al. (2004). The efficacy of laser therapy in wound repair: a meta-analysis of the literature. Photomed Laser Surg, 22(3), 241-247. https:// doi.org/10.1089/1549541041438623 
Wu, Z. \& McGoogan, J.M. (2019). Characteristics of and important lessons from the coronavirus disease 2019 (COVID-19) outbreak in China: summary of a report of 72314 cases from the Chinese Center for Disease Control and Prevention. JAMA, 323(13), 1239-1242. https:// doi.org/10.1001/jama.2020.2648

\section{A cikk APA szabály szerinti hivatkozása}

Sandra S. (2021). A COVID-19 (koronavírus okozta megbetegedés) kezelési lehetőségei a fizioterápia eszközeivel, kiemelt figyelemmel a fototerápia eddigi eredményeire. Belügyi Szemle, 69(3), 431-445. https://doi.org/10.38146/BSZ.2021.3.5 